\title{
Communication Studies in Argentina in the 1960s and '70s: Specialized Knowledge and Intellectual Intervention Between the Local and the Global
}

\section{Mariano Zarowsky \\ Universidad de Buenos Aires, zarowskymariano@gmail.com}

The emergence of communication studies in Latin America in the 1960s and '7os offers a productive viewpoint to think historically about social processes of emergence and consolidation of specialized discourses and knowledge. This essay aims to present some of the concepts and questions that have guided my research on the intellectual history of communication studies in Argentina. The concept of communication intellectuals, along with those of intellectual traditions and trajectories, offers valuable routes to address relationships between the production of specialized knowledge and broader social processes. In peripheral countries such as Argentina, it is also inescapable to ask about the global and transnational flow of ideas: How do the local and the global interact in the production of knowledge? How do we approach these relationships? Although this essay systematizes concepts and conclusions that refer to precise spatiotemporal coordinates, it also offers a more general reflection on ways of thinking and writing the intellectual history of communication studies as a contribution to its development in other regions and comparative analyses thereof.

At the beginning of the 1960s, a set of discourses began to crystallize in Argentina that took communication, mass media, and culture as a field of knowledge problems to be defined and legitimized.

Those who advanced these discourses established credentials to inter-
Mariano Zarowsky, "Communication Studies in Argentina in the 1960 and '7os: Specialized Knowledge and Intellectual Intervention Between the Local and the Global," History of Media Studies 1 (2021), https://doi.org/ 10.32376/d895aoea.42aoa7aa. 
vene in public debates and created distinct spaces of intellectual production and dissemination. Part of a broader reorganization of social and cultural hierarchies, they drew attention to new issues and developed new theoretical tools and ways of understanding the relations between intellectuals and society-all of which would shape the emergence of communication studies in the country. Here I refer to the reflections of Jaime Rest (1927-1979) on the relations between mass culture, popular culture, and media technologies in the late 1950s; to the work of Eliseo Verón (1935-2014) and Oscar Masotta (1930-1979) at the crossroads of sociology, structuralist linguistics, and psychoanalysis; to the bridges that Héctor Schmucler (19312018) was able to build between leftist militancy, editorial praxis, and knowledge production on the pages of the journals Pasado y Presente (1963-1965), Los Libros (19691976), and Comunicación y Cultura (19731985); to the blend of literary criticism, reflection on popular culture, and editorial activity that Aníbal Ford (1934-2009) engaged in while working at the publisher Centro Editor de América Latina and the journal Crisis (1973-1976); to the formulation of a political economy of communication by Heriberto Muraro (b. 1937) in the early 1970s; and to the political and epistemic debate that, during his exile in Mexico, Schmucler himself, together with Nicolás Casullo (19442008) and Sergio Caletti (1947-2015), led in the pages of the journals Controversia (1979-1981) and Comunicación y Cultura. ${ }^{1}$

The notion of communication intellectuals is a productive framework for thinking about these processes and historical figures. It does not refer to a group defined by its thematic or disciplinary specialization, but to intellectual contemporaries who located their own conditions and novel field of action in the space they carved out between a new type of theoretical problematic and political intervention. Investigating links between communication, culture, and technology; mass mediated messages and ideologies; cultural industries and popular cultures; collective action and social meanings; and between media and the reproduction or transformation of the social order; the communication intellectuals were projected as public figures because of their ability to give their research social, cultural, and eventually, political significance. The notion of communication intellectuals is productive to investigate how, in the 1960s and 1970s, thinking about communication in Argentina intervened in national debates and dilemmas. It sheds light on the ways in which these new modes of thought and specific social practices (university teaching, research, publishing magazines and books) represented an intervention into cultural issues - especially left-wing culture-and into more general political disputes within the context of an intense and dizzying process of hegemonic reconfiguration. From this perspective, the

\footnotetext{
${ }^{1}$ Mariano Zarowsky, Los estudios en comunicación en la Argentina: Ideas, intelectuales, tradiciones politico-culturales (1956-1985) (Buenos Aires: Eudeba, 2017).
} 
intellectual history of communication in Argentina places us at the intersection of two fields of problems. In an epistemic dimension, it confronts us with the question of the social conditions of the production of knowledge about the social. In a socio-historical dimension, the trajectories of communication intellectuals leads us to broader movements of culture and politics: We are dealing with actors and discourses that participated in a process of modernization and theoretical renewal that unfolded simultaneously with a sensitivity to radical change and a strong impulse towards public intervention.

To speak of a field of knowledge and discourses on communication and culture implies studying a process of formation rather than starting from pre-existing entities. Tracing a genealogy of this formation of discourses - which in Argentina took the form, a posteriori, of an area of specialized knowledge on communication-means exploring the spectrum of transformations, variants, and borrowings that shaped it and impacted an open array of relationships with other disciplines and emerging issues in the cultural and political fields. The intellectual and cultural history of communication studies in Argentina places us in a zone of crossings and porous borders: between knowledge from different disciplines, intellectual traditions, and theoretical currents (psychoanalysis, sociology, literary criticism, anthropology, linguistics, Marxism, structuralism); between the question of the scientific status of knowledge about the social and openings into a broader culture oriented toward change; and between the local scene and the transnational realm in which ideas are produced, circulated, and taken up.

Thinking about a culture in a specific national configuration implies, following Raymond Williams, accounting for the coexistence of heterogeneous, interacting elements, dominant and emergent, but also traditions arising from the past that are updated and recovered as active social forces. ${ }^{2}$ More than a succession of stages or currents, the notion of intellectual traditions allows us to capture the heterogeneity within an era and, above all, the intermixing and borrowings among the various formations that organized the communication intellectuals in Argentina during the 1960s and 1970s. Always in a state of dissolving, sometimes buried, other times on their way to being reformulated and updated (as they are always selective), the notion of intellectual traditions allows us to recognize both the common elements and the lines of differentiation among various formations, thus illuminating the textures and heterogeneous edges that modulated a cultural dynamic and its movements. ${ }^{3}$ Intellectual traditions operate as disciplinary frameworks and theoretical matrices that function as epistemic sources; as values and political cultures in which discourses are inscribed; and, finally, as ways of conceiving

History of Media Studies, vol. 1, 2021

\footnotetext{
${ }^{2}$ Raymond Williams, Marxismo y literatura (Buenos Aires: Las Cuarenta, 2009).
}

${ }^{3}$ For an analysis that uses Raymond Williams's cultural materialism to define traditions as the material contexts for the production of ideas and intellectual interventions, see Carlos Altamirano, Intelectuales: Notas de investigación (Buenos Aires: Norma, 2006), 127-29. 
and reflexively defining intellectual activity itself. The communication intellectuals in Argentina during the 1960s and 1970s were thus variably humanists, avant-gardists, and/or populists; organic and/or committed; modern and/or scientific; Marxists, liberals, socialists and/or Peronists; Gramscians and/or structuralists.

These intellectual traditions do not exist outside of temporal incarnations and specific biographical contexts. It is thus fitting to approach them as manifest through ideas, but also through the practices and vital vicissitudes of their privileged bearers: the subjects. 4 The notion of intellectual itinerary proves to be extremely productive in reconstructing these processes, where the work of thought is linked to and unfolds within the specificity of historical experiences. Thus, as opposed to biographical histories that are constructed through the prism of what Pierre Bourdieu called forms of biographical "illusion," 5 the notion of intellectual itinerary, as François Dosse writes, "makes it possible to encounter what was the present of the subject of a biography in its indeterminacy and ignorance." ${ }^{6}$ That is, in contrast to the traditional (linear and cumulative) history of the disciplines, it makes it possible to approach the cuts and discontinuities of which they are made. Finally, the notion of intellectual itineraries allows us to highlight the links that connect the formation of disciplines with broader socio-cultural networks.

Is the study of intellectual trajectories and traditions as connected with broader formations (beyond the strictly disciplinary) only productive in analyzing the early formation of a discipline, with its more fragile and porous boundaries with other knowledge and social spaces-or is it also useful for the study of more professionalized fields? In the same sense, were the connections between knowledge production and political practice a Latin American particularity of the second half of the twentieth century, or did they also mark other moments and geographies? There is no doubt that, in the 1960s and 1970s, Argentina-and Latin America in general experienced a moment of profound social transformation, intense political and cultural upheaval, and renewal of cultural and university institutions. This macro-social laboratory shaped artistic, academic, and intellectual practices and helped produce creative and original forms of knowledge in a number of specialized fields, communication studies among them. ${ }^{7}$

Correspondingly, it would be useful to think comparatively about the history of communication studies in Argentina and Latin America and the history of other schools or currents that also emerged in dense or agitated moments of history and shaped the field on a global scale. I am thinking, among other examples, of the Frankfurt School in its moment of emergence and then in its exile in the 1930s
${ }^{4}$ Horacio Tarcus, Marx en Argentina: Sus primeros lectores obreros, intelectuales y científicos (Buenos Aires: Siglo XXI, 2007), 53 .

${ }^{5}$ Pierre Bourdieu, "La ilusión biográfica," in Razones prácticas: Sobre la teoría de la acción, trans. Thomas Kauf (Barcelona: Anagrama, 1997).

${ }^{6}$ François Dosse, La marcha de las Ideas: Historia de los intelectuales. Historia intelectual (Valencia: Publicaciones de la Universidad de Valencia, 2006), 46.

\footnotetext{
7 On Chile as a "laboratory" for the field of communication in the 1970s, see Mariano Zarowsky, Del Laboratorio chileno a la comunicación-mundo: Un itinerario intelectual de Armand Mattelart (Buenos Aires: Biblos, 2013).
} 
and 1940s, or the Birmingham Cultural Studies circle in the 1960s and 1970s. A red thread binds these experiences-the one that unites social movement and the question of the dominated or subaltern, of their condition and destiny. The figure of the intellectual, exiled for political reasons, condenses in the 2oth century as a sort of "epistemological privilege" of the critical tradition: a character in transit, the exile sees through the prism of the world that abandons the society that shelters him, and with the prism of the new world, the society he leaves behind, gaining new perspectives. He does so from the standpoint of history's defeated, carrying on his shoulders a vital question: How did it come to this? Exile thus favors a kind of estrangement effect, with productive epistemic consequences. ${ }^{8}$

How can we study the interactions between the local and the global, which are so pronounced in peripheral countries such as Argentina? Knowledge about communication in Argentina and Latin America was largely configured out of regional articulations interacting with global processes. The connections between researchers in Argentina and Chile in the 196os and '7os and the contemporaneous but differentiated circulation of structuralism and French semiology in both countries is a good example, as Eliseo Verón has previously observed. ${ }^{9}$ The examination of this interaction then requires work on different scales, where the study of local scenarios proves vital: It is a matter of highlighting the specific debates, national intellectual traditions, and local conjunctures within which specialized discourses on communication emerged and acquired their prominence and particularity. This does not imply ignoring other dimensions. On the contrary, this "national cut," as José Aricó calls it, ${ }^{10}$ helps us better gauge how local practices of knowledge production interact with the international circulation of ideas. It was through specific activities in local society and culture that the communication intellectuals in Argentina linked themselves to international flows of ideas, making original appropriations and contributions. It is in the interaction between the global and the local, in short, that knowledge about the social is produced; and it is in active appropriations and local uses that new knowledge is generated with materials drawn from other contexts of production. ${ }^{11}$ Situating ourselves in this space of interaction also allows us to highlight the ways in which the capacity to manage transnational flows of information and knowledge helps to create hierarchies and organize positions within the peripheral academic and intellectual field. ${ }^{12}$

The history of communication studies in Argentina represents, in short, a productive entry point to analyze social processes of constructing knowledge about the social and, more broadly, to address the relationships among intellectuals, culture, and politics in the
${ }^{8}$ On the "epistemological privilege" of exile and the point of view of the "vanquished of history" in the critical tradition, see Enzo Traverso, La historia como campo de batalla: Interpretar las violencias del siglo XX (Buenos Aires: Fondo de Cultura Económica, 2012); and Traverso, Melancolía de izquierda. Marxismo, historia y memoria (Buenos Aires: Fondo de Cultura Económica, 2018). For an analysis of exile in the specific case of communication studies in Argentina, see Mariano Zarowsky, "Del exilio a los nuevos paradigmas: los intelectuales argentinos de la comunicación en México (de Controversia a Comunicación y cultura)," Comunicación y sociedad 12, no. 24 (2015); and Zarowsky, Del laboratorio chileno a la comunicación-mundo.

${ }^{9}$ Eliseo Verón, “Acerca de la producción social del conocimiento: el 'estructuralismo' y la semiología en Argentina y Chile," Lenguajes, 1 (April 1974).

${ }^{10}$ José Aricó proposes this "national cut" in his study of the travels of Antonio Gramsci's thought in Latin America. He argues that to approach this "geography" an "inversion of the terms" is required in "conditions of showing the existing connections between processes of reality and processes of the elaboration of theory." He adds: "a deeper inquiry into the demands of reality that movements in society and culture carry with them when they appropriate his [Gramsci's] reflections implies dilating our search to such extremes that only a 'national' cut makes it possible." José Aricó, La cola del diablo: Itinerario de Gramsci en América Latina (Buenos Aires: Siglo XXI, 2005), 43.

${ }^{11}$ Federico Neiburg and Mariano Plotkin, "Intelectuales y expertos: Hacia una sociología histórica de la producción del conocimiento sobre la 
country and region in the 1960s and '7os. The itinerary of communication intellectuals in Argentina can be read as a chapter of the country's recent history. At the same time, in this essay, from the perspective that guided my research and the conclusions I reached there, I've made suggestions and raised questions about the intellectual history of communication studies as a field which I hope might open up possibilities for inquiry in and about other locations.

\section{Bibliography}

Altamirano, Carlos. Intelectuales: Notas de investigación. Buenos Aires: Norma, 2006.

Aricó, José. La cola del diablo: Itinerario de Gramsci en América Latina. Buenos Aires: Siglo XXI, 2005.

Bourdieu, Pierre. "La ilusión biográfica." In Razones prácticas: Sobre la teoría de la acción, translated by Thomas Kauf, 74-83. Barcelona: Anagrama, 1997.

Dosse, François. La marcha de las ideas: Historia de los intelectuales. Historia intelectual. Valencia: Publicaciones de la Universidad de Valencia, 2006.

Neiburg, Federico, and Mariano Plotkin, "Intelectuales y expertos: Hacia una sociología histórica de la producción del conocimiento sobre la sociedad en la argentina." In Intelectuales y expertos: La constitución del conocimiento social en la argentina, edited by Federico Neiburg and Mariano Plotkin, 15-30. Buenos Aires: Paidós, 2004.

Plotkin, Mariano, and Eduardo Zimmermann, "Introducción, saberes de Estado en la Argentina, siglos XIX y XX." In Los saberes del Estado, edited by Mariano Plotkin and Eduardo Zimmermann, 9-28. Buenos Aires: Edhasa, 2012.

Tarcus, Horacio. Marx en Argentina: Sus primeros lectores obreros, intelectuales y científicos. Buenos Aires: Siglo XXI, 2007.

Traverso, Enzo. La historia como campo de batalla: Interpretar las violencias del siglo XX. Buenos Aires: Fondo de Cultura Económica, 2012.

- Melancolía de izquierda: Marxismo, historia y memoria. Buenos Aires: Fondo de Cultura Económica, 2018.

Verón, Eliseo. "Acerca de la producción social del conocimiento: el 'estructuralismo' y la semiología en Argentina y Chile." Lenguajes 1 (1974): 96-126.

Williams, Raymond. Marxismo y literatura. Buenos Aires: Las Cuarenta, 2009.

Zarowsky, Mariano. Los estudios en comunicación en la Argentina: Ideas, intelectuales, tradiciones político-culturales (1956-1985). Buenos sociedad en la Argentina," in Intelectuales y expertos: La constitución del conocimiento social en la argentina, eds. Federico Neiburg and Mariano Plotkin (Buenos Aires: Paidós, 2004).

12 Mariano Plotkin and Eduardo Zimmermann, "Introducción, saberes de Estado en la Argentina, siglos XIX y $\mathrm{XX}$, " in Los saberes del Estado, eds. Mariano Plotkin and Eduardo Zimmermann (Buenos Aires: Edhasa, 2012), 20-21. 
Aires: Biblos, 2017.

. "Del exilio a los nuevos paradigmas: los intelectuales argentinos de la comunicación en México (de Controversia a Comuni-

cación y cultura)." Comunicación y sociedad 12, no. 24 (2015): 12760.

. Del laboratorio chileno a la comunicación mundo: Un itinerario intelectual de Armand Mattelart. Buenos Aires: Biblos, 2013.

History of Media Studies, vol. 1, 2021 